\title{
Kerala's Innovations and Flexibility for Covid-19 Recovery: Storytelling using Systems Thinking
}

\author{
Arun A. Elias $^{1}$ (D)
}

Received: 26 October 2020/Accepted: 12 March 2021/Published online: 5 April 2021

(C) Global Institute of Flexible Systems Management 2021

\begin{abstract}
During the early five months of the first phase of the Covid-19 pandemic, the South Indian state of Kerala regularly appeared in world media, presenting an impactful case of Covid-19 innovations. The purpose of this article is to uniquely present Kerala's success of flattening the Covid-19 curve during that period, employing storytelling using systems thinking. Contributing to the literature stream linking flexible systems management and systems thinking, this study presents the interconnected whole of Kerala's Covid-19 innovations for pandemic management. The reference mode that was developed using the systems thinking and modelling methodology confirmed Kerala's exemplary performance in flattening the Covid-19 curve during the first five months of 2020. The systems model built showed six feedback loops explaining how Covid-19 spreading was controlled in Kerala by different types of innovations and an effective public health system. Overall, with a strong inbuilt social fabric, experienced leadership that withered Nipah-virus outbreak, and robust public health system at its advantage, Kerala flattened the Covid-19 curve using its intertwined social, policing, communication and technological innovations.
\end{abstract}

Keywords Covid-19 innovations · Flexible systems · Kerala $\cdot$ Systems thinking

Arun A. Elias

arun.elias@vuw.ac.nz

1 Wellington School of Business and Government, Victoria University of Wellington, Wellington, New Zealand

\section{Introduction}

During the first half of 2020, the state of Kerala in Southern India frequently appeared in Indian and international media for the exceptional management of Covid-19 pandemic. MIT Technology Review presented an article in April 2020 explaining how Kerala was flattening the Covid-19 curve through extreme levels of social assistance and contact tracing (Faleiro 2020). BBC titled Kerala as the salient exception in the battle against Covid-19 in India (Biswas 2020), while Times of India named Kerala as India's Covid-19 model state (Prakash 2020). Kerala presents an interesting and impactful case of innovative and flexible approaches towards Covid-19 recovery, especially during the first five months of the Covid-19 pandemic.

With 33.4 million population, 860 persons/sq.km population density and US $\$ 110$ billion gross state domestic product (GSDP) at current prices, Kerala is unique compared with other Indian states. (Kerala State Planning Board 2019). About 2.3 million Keralites work overseas with majority based in the Persian Gulf and foreign remittances contribute around one-third of Kerala's GSDP (Manoj 2016). Politically, apart from the Italian principality of San Marino, Kerala became the first democratically elected communist government in the world in March 1957 (Nossiter 1982). When Covid-19 hit sixty-three years later, Kerala is again run by a democratically elected communist government, specifically the Left Democratic Front, a coalition led by the Communist Party of India (Marxist) with Pinarayi Vijayan as the Chief Minister (CM).

Kerala reported the first positive coronavirus case in India on 30 January 2020, when three medical students from Wuhan University returned home. But the state was prepared under the leadership of Shailaja teacher, a former 
science teacher and the current health minister, who had already proved leadership capabilities by successfully handling Kerala's 2018 Nipah-virus outbreak (WHO 2018). Before the second wave of cases arrived through a set of non-resident Keralites returning from Italy in early March 2020, the first three had recovered. March and April 2020 saw new cases rising, reaching a maximum of 39 on March 27, followed by a slow reduction, hitting zero new cases in early May (Fig. 1). As of 10th May, Kerala had 512 confirmed cases, 489 recovered, with only 20 cases remaining active and just three deaths while other states were struggling (GoK Dashboard 2020). Kerala became an exemplar for flattening the Covid-19 curve during the first phase of the pandemic.

The state's triumph in arresting the pandemic can be contributed to a range of individual innovations facilitated by multiple actors in the system. However, this case argues that Kerala's success cannot be confined to any individual innovation, but it was the holistic approach, integrating different innovations that made the difference. To understand this, first, the different factors that contributed to Kerala's Covid-19 innovation need to be identified, followed by a holistic analysis of the system using approaches like systems thinking. Therefore, this study is designed with an overall purpose of analysing Kerala's success in flattening the Covid-19 curve during the first phase of the pandemic using a systems thinking approach. This article includes relevant literature, methodology employed, data collected, and models developed.

\section{Systems Thinking in Flexible Systems Management Literature}

A system is often referred as a complex of interrelated parts and systems thinking as the process of thinking using systems ideas (Checkland 1985). The influence of system structure on system behaviour is fundamental to systems thinking (Richmond 1994). Some of the main principles of systems thinking include visioning the big picture, longterm instead of short-term thinking, cause and effect thinking and either-or thinking (Elias 2008). One way of classifying systems thinking literature is to group them as hard (e.g. Coyle 1996), soft (e.g. Checkland 1985), critical (e.g. Ulrich 1983), and multimethodology (e.g. Brocklesby and Cummings 1995). Hard systems thinking conceptualises models as representations of the real world, soft systems thinking use models as discussion tools and critical systems thinking is recognised as a critical discourse focussing on boundary critiques. A mix of systems thinking methods, combining hard, soft or critical approaches for analysing complex problems are used in multimethodology (Davies et al. 2005; Eidelwein et al. 2018).

While proposing Flexible Systems Management as an evolving paradigm, Sushil (1997) recognises that the foundations of this paradigm are rooted in systems thinking. He conceives flexibility as the exercise of free will or freedom of choice. A systemic concept of flexibility encompasses the major attributes of spectral, integrative, interactive, innovative, and fuzziness characters. Arguing

\section{New Cases}

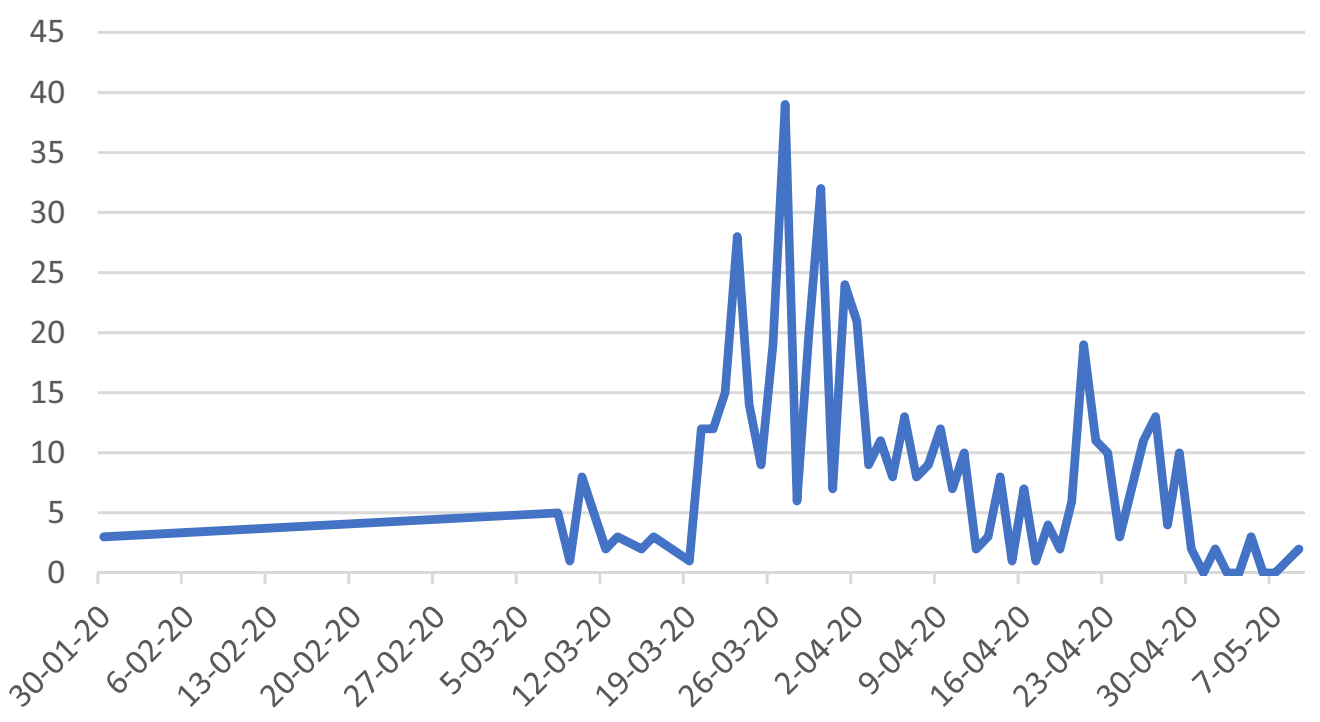

Source: GoK Dashboard (2020). Accessed on 10 May 2020.

Fig. 1 New cases in Kerala. Source GoK Dashboard (2020). Accessed on 10 May 2020 
that paradigms can emerge as an antithesis of the traditional paradigms, Sushil (1997) draws on the works of systems thinkers like Ackoff (1981) who found systems age as a synthesis of the machine age and its antithesis, which is still being formulated.

In the evolution of flexible systems management literature, researchers further explored the use of systems thinking in analysing research problems in the field. For example, Elias (2019) used participative systems thinking approaches for developing flexible strategic interventions for managing stakeholder conflict in a transport infrastructure project. Chowdhury and Jangle (2018) developed a conceptual framework using critical systems thinking for community engagement and flexibility in micro-insurance schemes. Sushil (2017) explained that flexible systems management is an iterative process in search of a balance between hard systems thinking that focuses on optimisation and soft systems thinking that focuses on learning. Researchers like Gorod et al. (2008) and Jovel and Jain (2009) explored the context of 'system of systems' for managing flexibility in complex settings like the Defence Industry.

The concept of innovation has also started to permeate into the Flexible Systems Management literature. For example, Haleem et al. (2018) used a flexible system approach to identify the requisites of product innovation management. Bishwas (2015) conducted an empirical study to claim that innovation and flexibility are two strategic intents for attaining organisational vitality. According to Wadhwa et al. (2007), when healthcare systems are viewed as flexible systems, there is more scope to promote innovations in the system. While research linking innovation and flexibility is growing, a dominant stream in the innovation literature, innovation systems, which uses a systems approach to innovation (Carlsson et al. 2002; Malaviya and Wadhwa 2005) is still missing in the Flexible Systems Management literature.

Researchers are also showing a renewed interest in contributing to the pandemic management literature after the emergence of Covid-19 (e.g. Baveja et al. 2020; Polas and Raju 2021) with many focussing on Covid-19 innovations (e.g. George et al. 2020; Paul and Chowdhury 2020). Research on convergence innovation, capable of an exponential fusion of objects, technologies, and strategies (Lee and Trimi, 2020); rapid innovation with an ultrafast approach to innovation (Von Krogh et al. 2020) and frugal innovation reducing complexity and cost (Sarkar 2020) to manage the pandemic are emerging in the pandemic management literature. Calls for crowdsourcing, cuttingedge technologies, and innovations while working from home (e.g. George et al. 2020) are also resurfacing in the pandemic management literature.
From a critical analysis of this literature, this study found the need for more in-depth empirical studies, employing systems thinking principles, for analysing successful innovation systems for pandemic management within the flexible systems management literature. There is potential to research national innovation systems (Nelson and Green, 1996), regional innovations systems (Höglund and Linton 2017), technological innovation systems (Bergek et al. 2008), and a movement from triple helix to quadruple/quintuple-helix innovation system models. Triple helix innovation systems involve interactions between university, industry, and government, while civic society is added to the three in quadruple and the overarching environment is also added to the four in quintuple-helix innovation systems (Carayannis et al. 2017). Thus, this study is aimed at developing a case study of Kerala during the first phase of Covid-19 outbreak, using a systems thinking approach, to capture the underlying structure of its innovation system that was responsible for flattening its Covid19 curve.

\section{Methodology}

This study used the system's thinking and modelling methodology (Maani and Cavana, 2007) to develop Kerala's case of Covid-19 innovation. System's thinking and modelling are grounded on the System Dynamics approach (Sterman 2000). Specifically, two phases of the methodology were used in this study, problem structuring followed by causal loop modelling.

The first phase of the study involved structuring the problem systemically. This phase involved the development of a reference mode, also known as behaviour over time (BOT) graph (Maani and Cavana 2007). This was followed by the identification and analysis of stakeholders who are involved in the case (Elias and Zwikael 2007) and the development of an overall systems diagram. Data for this phase were mainly collected using secondary sources including Indian and international media reports and publicly available government publications. Some specific examples include BBC news (e.g. Biswas 2020), Express Computer (e.g. Dass 2020), Hindustan Times newspaper (e.g. Babu 2020), Malayala Manorama (2020), Press Trust of India (2020), The Hindu newspaper (e.g. Athira 2020), Times of India newspaper (e.g. Prakash 2020), Economic Review 2019 by Kerala State Planning Board (2019), and Nipah virus- India report by WHO (2018).

The second phase of the study involved the development of a causal loop model. A causal loop model is a systems model drawn by linking the variables in a system using the cause and effect logic (Coyle 1996). It represents the system structure using the feedback loops interacting in the 
Table 1 Interview participants

\begin{tabular}{|c|c|c|}
\hline Participant profession/industry & Pseudonym & Gender \\
\hline \multirow[t]{6}{*}{ Business school academics from Kerala } & BA 1 & Male \\
\hline & BA 2 & Female \\
\hline & BA 3 & Female \\
\hline & BA 4 & Female \\
\hline & BA 5 & Male \\
\hline & BA 6 & Female \\
\hline \multicolumn{3}{|l|}{ Start-up owners from Kerala } \\
\hline Information Technology & SO 1 & Male \\
\hline Information Technology & SO 2 & Male \\
\hline Education & SO 3 & Male \\
\hline Health & SO 4 & Male \\
\hline Health & SO 5 & Female \\
\hline \multicolumn{3}{|l|}{ Business owners from Kerala } \\
\hline Pharmaceuticals & BO 1 & Male \\
\hline Hospital & BO 2 & Male \\
\hline Tourism Operator & BO 3 & Male \\
\hline Bakery & BO 4 & Male \\
\hline \multirow[t]{3}{*}{ Health professionals in Kerala } & HP 1 & Female \\
\hline & HP 2 & Female \\
\hline & HP 3 & Female \\
\hline \multirow[t]{3}{*}{ Volunteers involved in Covid-19 } & VO 1 & Male \\
\hline & VO 2 & Female \\
\hline & VO 3 & Female \\
\hline
\end{tabular}

system. Data for this phase were mainly collected using zoom interviews with 21 representative stakeholders (Table 1). Overall, systems thinking allowed storytelling while mapping system behaviour and structure (Galanakis 2006).

\section{Problem Structuring}

Kerala's exemplary performance in flattening the Covid-19 curve during the first five months of 2020 can be captured using a reference mode (Fig. 2). A reference mode is a systems thinking tool that uses the main variables in the system to capture the behaviour of the system (Maani and Cavana, 2007). It shows an increase followed by a gradual flattening in the number of confirmed cases and an increase in the number of recovered cases. It also shows the number of active cases declining and a very low number of deaths (0.56\% mortality-rate) over time.

Problem structuring also involves identifying and analysing the stakeholders (Elias 2017) who are involved in Kerala's Covid-19 innovations. A traditional stakeholder map (Fig. 3) identified the main groups of stakeholders and their dyadic relations. The study does not include a detailed stakeholder analysis (Elias et al. 2001) but it highlights some interesting stakeholder networks (Rowley 1997) formed to realise Kerala's Covid-19 innovation system.

In addition to the traditional problem structuring methods like reference mode and stakeholder analysis, an overall system's diagram was also constructed in this study (Fig. 4).

This diagram shows the interconnections among different parts in the system. For example, the social innovations at the outer-level are connected to other innovations in the same level as well as the NGO sector in the middle-level, and thereby contributing to Covid-19 innovations in the inner-level which helps in flattening the curve. Similarly, political innovations through public sector organisations like the Kerala Police also contribute to flattening the curve. It also captures other similar connections like technological innovations through start-up sector, economic innovations through private sector, political innovations through public sector and historical learnings through health sector. This overall system's diagram formed the basis for constructing the causal loop model (Fig. 5). 


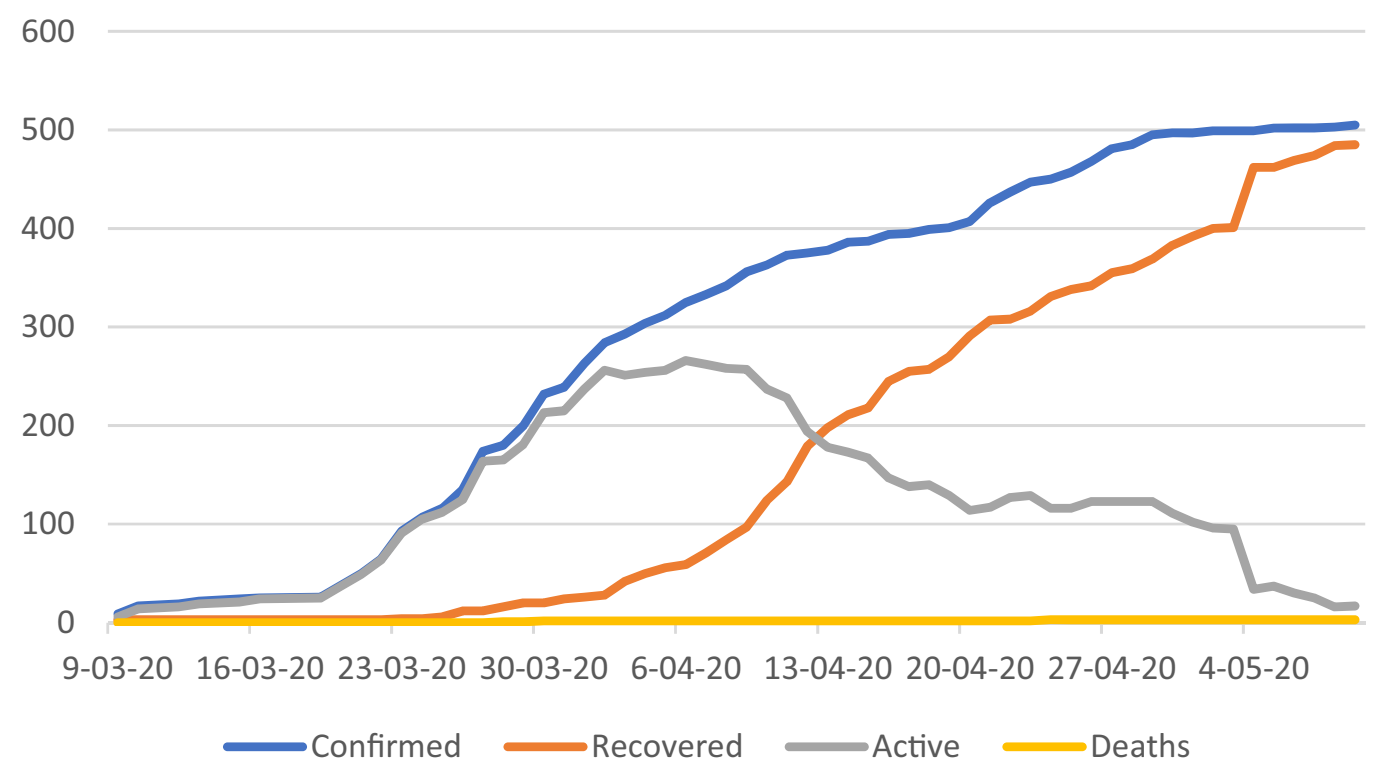

Source: Based on GoK Dashboard (2020). Accessed on 10 May 2020.

Fig. 2 Reference mode. Source Based on GoK Dashboard (2020). Accessed on 10 May 2020

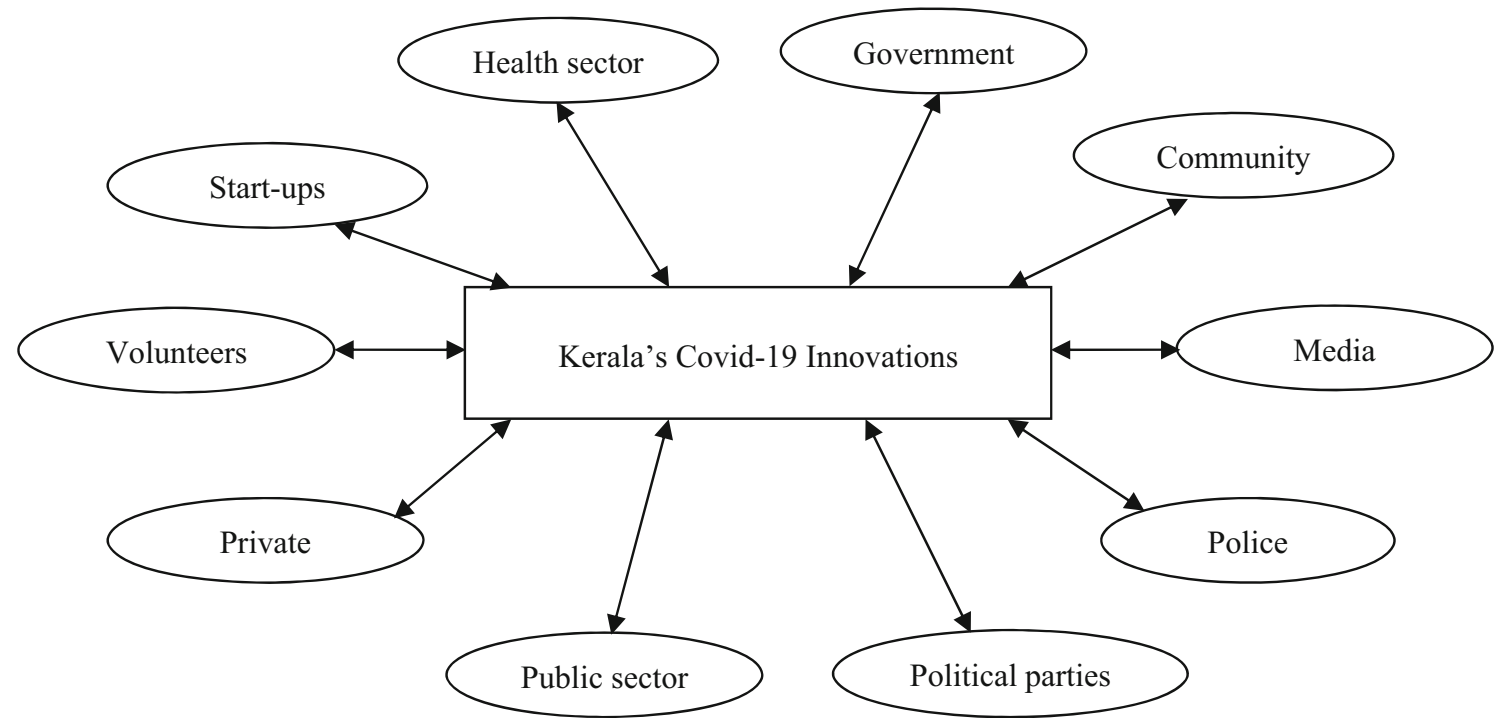

Fig. 3 Stakeholder map

\section{Causal Loop Modelling}

For developing the causal loop model, this study first collected factors affecting the system from each participant in Table 1 . These factors were compared with the secondary data and consolidated and classified into six groups (Table 2). In addition to the factors that affected Covid-19 innovations in Kerala, three interesting examples of Covid19 innovations are also presented.

\section{Community Kitchens}

Community kitchen is an exemplar of Kerala's social innovation, witnessed during the Covid-19 pandemic. Taking up Chief Minister Vijayan's call that 'no one must go hungry during the Covid-19 lockdown', community kitchens started providing food for free to vulnerable sections of the society during the lockdown from 26th March, immediately after CM's announcement (Press Trust of India 2020). Just in 2 weeks, a total of 1255 community 


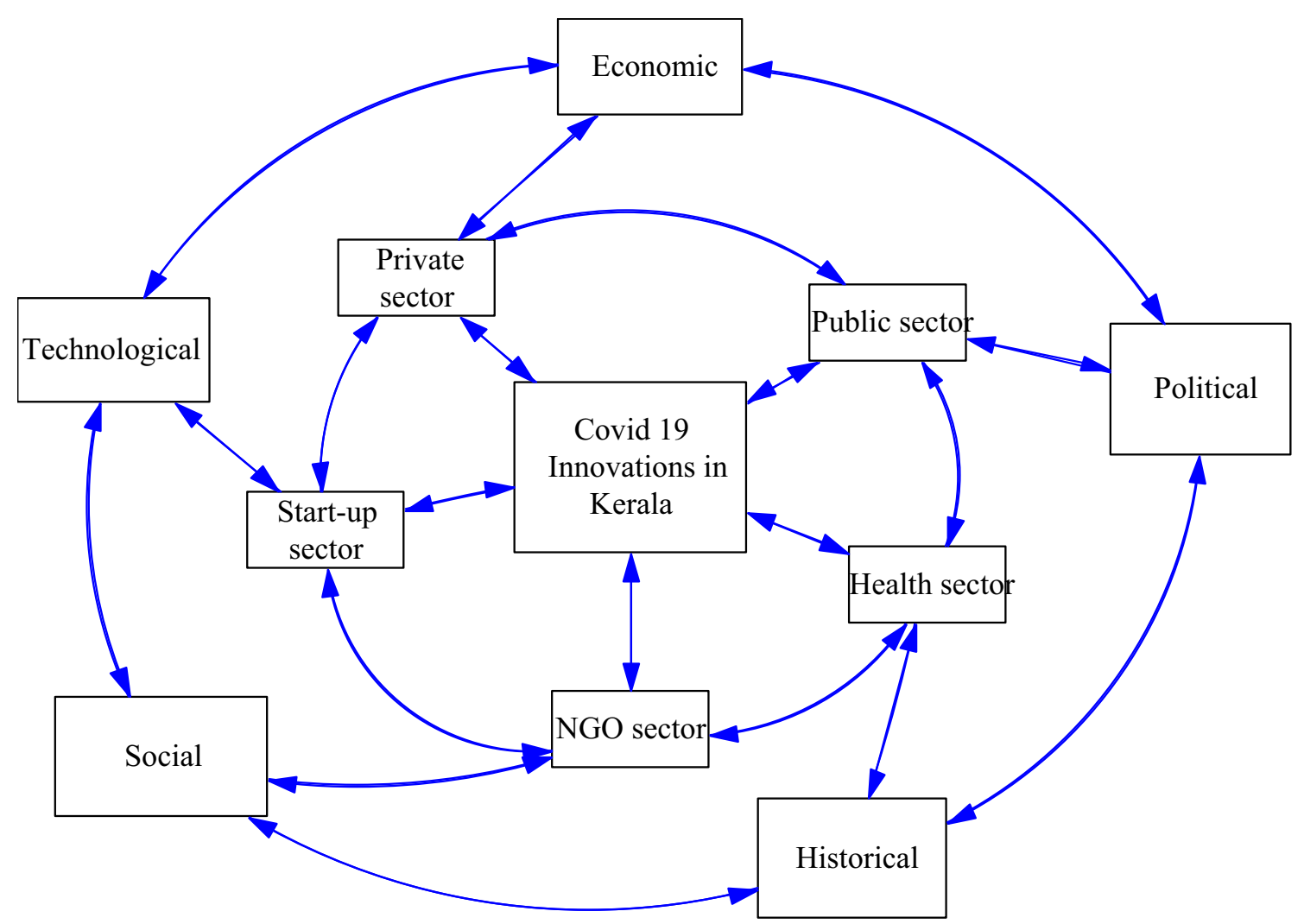

Fig. 4 Overall systems diagram

kitchens that included 135 in municipal corporations and 941 panchayats in Kerala were preparing food and handing out 250,000-280,000 packets of food every day (The Hindu 2020). Following social distancing and other precautionary measures, each community kitchen used at least one contact phone number to activate the free food delivery process to weaker sections of the society including homeless people, destitute and migrant labourers at their doorstep. Community kitchens also show an interesting example of stakeholder networking (Rowley 1997): initiated by the government; led by local self-governing bodies and 'Kudumbashree' - the state's women community network; sourcing locally made raw materials through 'Supplyco'-Kerala's civil supplies corporation; with the help of volunteers groups like 'Agrogya sena' (Health army), 'ASHA workers', rural child care-centre teachers, WhatsApp groups and community members; to cook and distribute food after identifying needy people. Thalassery town in the district of Kannur saw an exceptional network between two rival political parties when Communist Marxist party's youth wing, Democratic Youth Federation of India (DYFI) and Rashtriya Swayamsevak Sangh (RSS), ardent supporters of Bhartiya Janata Party (BJP) worked together in a community kitchen despite the rivalry that had claimed 200 lives in the past (Babu 2020). As a social innovation, community kitchens helped in controlling deaths to a bare minimum while flattening the Covid-19 curve by avoiding potential agitations by migrant workers (Malayala Manorama 2020) and other negative social conduct that could have risked the positive effects of lockdown.

\section{Policing Innovations}

The measures taken by Kerala Police (KP) during Covid-19 lockdown had intertwined elements of policing innovations. To start with, KP firmly applied lockdown rules, checking most of the roads and preventing any needless traffic. For essential workers and public with legitimate needs, an affidavit system declaring why they were travelling was implemented. Permission was given for unavoidable necessity. Innovatively, an option to create a web-based e-pass that can be delivered to a mobile phone was also created. At the next level, a platform for the surveillance of high-risk people under quarantine was developed by KP's cyber cell using geofencing. Employing global positioning system (GPS), RFID tags, Wi-Fi, or mobile phone tracking, such geofences created a virtual boundary and alerted KP when someone stepped outside this boundary. KP also developed a network of 300 drones with the help of private players to scan every corner of Kerala, and making announcements through these drones, 


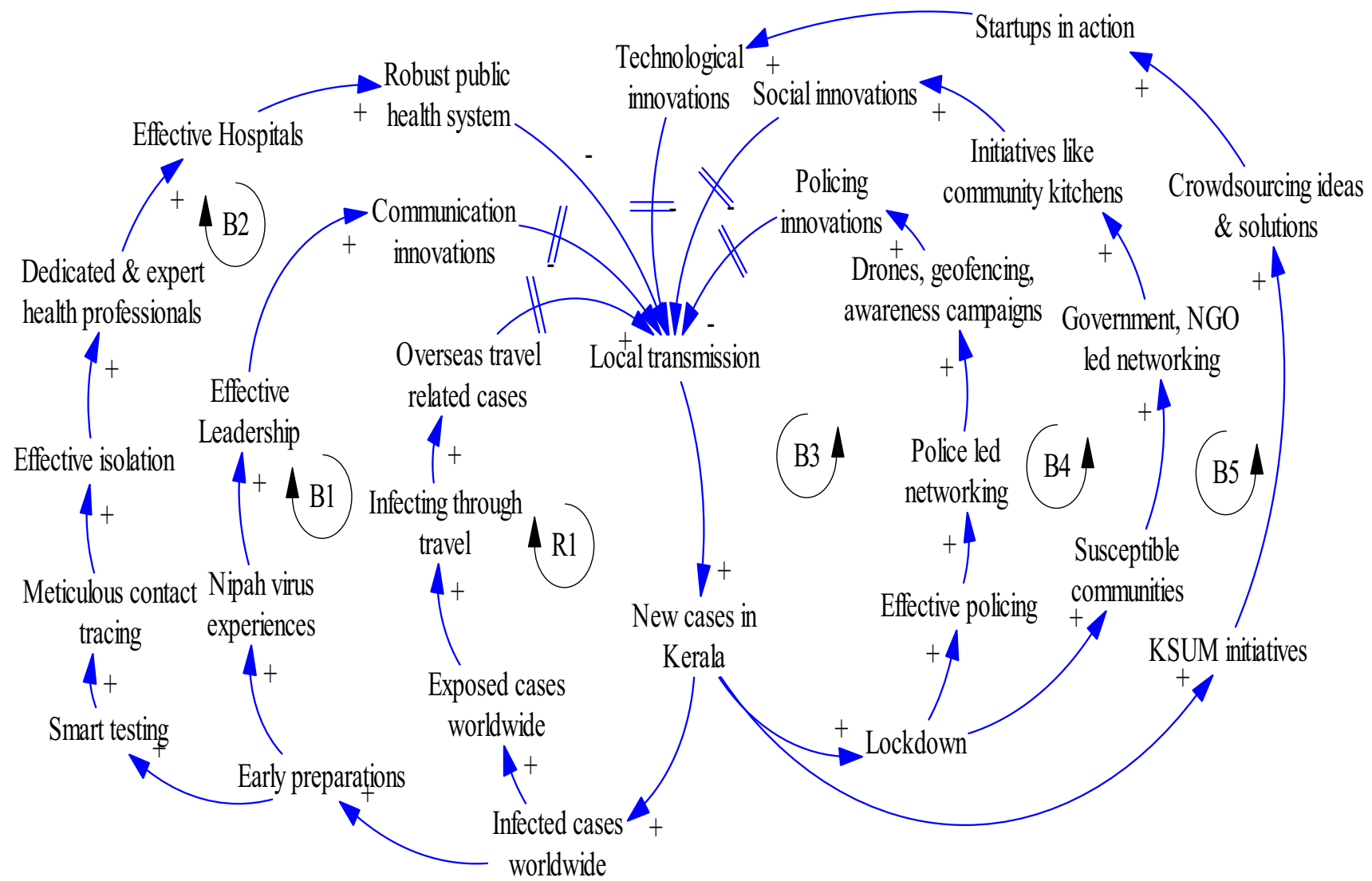

Fig. 5 Causal loop model

Table 2 List of factors

\section{Volunteering innovations}

Creating a volunteer force with $22-40$ years age

Creating community kitchens

Mobilising ASHA workers or accredited social health activists

Creating groups for self help

Disaster management experiences

Successful handling of Nipah-Virus outbreak in 2018

Successful handling of a major flood in 2019

\section{Preparedness}

Early preparation when Wuhan reports appeared

Early implementation of lock down

Closing schools and other educational institutions early

Policing Innovations

Videos of handwashing and break-the-chain

Development of drones and geofencing

Firm policing in most roads

Leadership

State govt. leadership by chief minister and health minister

Efficient departments within government

Dedicated collectors and leadership in local govt
Public health system

Assertive treating, tracing, isolating and testing Health worker protection -e.g. PPE, quarantine Special care for young children and elderly citizens Increasing tests/population; a helpline called DISHA

Hospital networks; Active primary level health centres

Thorough route mapping and contact tracing

Social factors

India's highest Human Development Index in Kerala

Keral's literacy rate $(93.91 \%)$ - highest in India

Co-operation, awareness and cleanliness of Kerala's public

Media

10 Kerala-wide TV news channels providing hourly news

15 newspapers- one of them with 24 million circulation

Virus movie in Malayalam

Start-ups

Kerala State Startup Mission (KSUM)'s crowdsourcing efforts Developing robots providing sanitiser and Covid-19 advice Govt of Kerala dashboard on Covid-19

Startup Mission's drive for ideas \& solutions -e.g. Breakcorona 
using speakers. With the support of Indian Medical Association, KP created Blue Tele-med, a telemedicine mobile application, facilitating free video consultation with doctors (Dass 2020). These innovations reached a different level when KP's media cell used popular Malayalam movie songs through social media to create Covid-19 awareness videos. Performed by six uniformed policemen, the 'handwashing dance video' showing the right way to wash hands to the tune of a Malayalam movie song was hailed internationally. Its 'break-the-chain video' shows a scared man facing a computer-generated coronavirus and running for his life before deciding to take a stand. Supported by a police officer and a doctor, he uses hand sanitiser, wears a protective face mask, and charges at his foe, thus vapourising the coronavirus (Athira 2020). Both videos went viral, totalling over 4 million views. Stakeholder networks involving KP, doctors, government, social media, start-ups, and movie industry played a vital part in this innovation system, thereby flattening the Covid-19 curve.

\section{Kerala Start-up Mission (KSUM) and Start-ups}

A former Dean of Kerala's premier business school, the Indian Institute of Management Kozhikode (IIMK) as its Chief Executive, KSUM was well positioned to implement triple/quadruple or even quintuple-helix innovation system models (Carayannis et al. 2017) during the Covid-19 pandemic. KSUM's 'Break Corona' crowdsourcing call for innovative ideas and solutions generated 1947 ideas and 351 solutions as of 10th May 2020, realising its role as the nodal agency in Kerala's start-up ecosystem. Start-ups also played their role. 'Asimov robotics' developed economical robots for dispensing hand sanitisers at office and public building entrances; autonomous delivery of food, medicine, and consumables inside isolation wards; disinfecting used items; and assisting patients to communicate with doctors and others. 'Qkopy' created 'Government of Kerala (GoK) Direct' app for Kerala government, delivering real-time information and Covid-19 alerts. 'QuikDr Healthcare's free app for government offered telemedicine solutions, helping patients to virtually consult top doctors. Other examples by KSUM incubated start-ups include applications developed by 'Thought Ripples' for Keralawide patient data management, including their primary and secondary contacts and 'iBoson's software helping government's essential services like workplace access for designated staff (Raval 2020). Overall, these technological innovations were realised through multiple stakeholder networks between government, KSUM, different start-ups, NGOs, innovators, partners like Indian Medical Association and technology companies, community and educational institutions. The contribution of technological innovations in isolation towards flattening Kerala's Covid-
19 curve was limited, but its power lies in the synergy it created by complementing other innovations in public health, social, economic, political, and policing, from a systems thinking perspective.

\section{Causal Loop Model}

Using the factors and the three highlights as a base, the causal loop model created (Fig. 5) consists of six interacting feedback loops that captures the system structure. These feedback loops are explained, thereby telling Kerala's Covid-19 success story.

\section{Covid-19 Spreading Loop (R1)}

The story can start at the variable, 'infected cases worldwide' that increases people exposed to Covid-19, who may get infected while travelling. Following this path, Kerala's first Covid-19 case came from Wuhan through overseas travel. After a delay, these cases can become 'local transmission' which increases 'new cases in Kerala', contributing to cases worldwide. Technically, this is a reinforcing feedback loop and if uncontrolled, it could result in exponential Covid-19 growth in Kerala. This feedback loop can be summarised using the words of two interviewees:

"As you may have seen on TV, our Covid-19 came through travel......Wuhan students, Italian family" (HP 2).

"Kerala is a state of non-resident Indians. When they returned home, they bought Coviid-19 to Kerala" (BA 5).

\section{Preparedness, Communication Innovations Loop (B1)}

Kerala was prepared. Experiences from successfully handling 2018 Nipah-virus outbreak under the leadership of Shailaja and Vijayan helped. This resolute leadership's effective 'communication innovations' like daily TV updates and break-the-chain campaign contributed to slowing-down 'local transmission', thereby completing first of the six balancing loops. This feedback loop can be captured using the following quotes:

"We learned from Nipah-virus times.......we were prepared....our communist government showed excellent leadership" (VO 2).

"Shailaja teacher's leadership was too good. She also had the experience from Nipah......Pinarayi Vijayan was also very good......his daily TV updates were really helpful" (BO 4). 


\section{Effective Public Health Loop (B2)}

Kerala's 'robust public health system' contributed immensely. 'Smart-testing' under 1000 tests/day, leading to 'meticulous contact tracing' using route-maps and 'effective isolation' with 170,000 isolations at the peak, helped 'dedicated \& expert health professionals' to maintain 'effective hospitals' without overcrowding. This balancing loop can be validated using the following two quotes:

"You have to understand, Kerala always had an excellent public health system.......Keralites are usually neat and look after their hygiene... see our low-level workers who come to town in the evening after a good shower"(BA 2).

"The protocols were followed strictly......testing, contact tracing, isolation....we always do our job sincerely." (HP 1).

\section{Policing Innovations Loop (B3)}

Before India's 21-day lockdown, CM had declared Keralawide 'lockdown' on 23rd March. 'Effective policing' by KP followed. Innovatively, 'KP led networking' with startups, media, etc., saw KP using 'drones, geofencing, and awareness campaigns'. Such 'policing innovations' resulted in households, religious/community institutions, and prisoners producing masks, thereby reducing local transmissions, although not immediately. This balancing loop can be captured using the following two quotes:

"Kerala Police went over and above their usual duties. They came to start-ups and we helped them....look at the drones and geofencing." (SO 3).

"Have you seen the Covid-19 video by our police?......creative and effective" (BO 3).

\section{Social Innovations Loop (B4)}

The 'lockdown' exposed 'susceptible communities' like the poor, old, and migrant workers to destitution. Sensing this, stakeholder networks including NGOs, government, community, and political parties sprang into action. 'Initiatives like community kitchens' became excellent 'social innovations' that arrested 'local transmission', in the longterm. Technically, this is a balancing loop and it can be explained using the following two quotes:

"Our current government have a socialist outlook......party workers have deep connections in the community and knows their needs......community kitchen is an example" (BA 1).
"I helped in a community kitchen......we are used to voluntary work....I did it during floods too" (VO 1).

\section{Technological Innovations Loop (B5)}

Start-up sector also showed responsibility. 'KSUM initiatives' like 'crowdsourcing ideas and solutions' put several 'start-ups in action'. 'Technological innovations' like telemedicine apps and robots developed by start-ups helped in controlling 'local transmission', in the long-term.

"The youth of Kerala helped the cause through their contributions in the start-up sector (SO 2).

"Kerala has so many young Engineers who are technically qualified. They wanted to help....technological innovations came from them" (SO 1).

The combined effect of these six feedback loops contributed to Kerala's success. The three examples presented before are embedded in this model. For example, community kitchen contributes to loops B1 and B4, policing innovations form loop B3 while Kerala start-up mission (KSUM) and start-ups contribute to loop B5. Although not explicitly captured in this model, economic innovations through private sector like door-to-door medicine delivery by DHL Kochi to Keralites (Mathrubhumi 2020) and political innovations like CM's joint press-conferences with the opposition leader (The New Indian Express 2020) also contributed.

\section{Conclusions}

Kerala presents an impactful case of innovation and flexibility for Covid-19 recovery. Kerala's case is presented uniquely in this article, employing storytelling using a systems thinking approach (Galanakis 2006). Instead of presenting any one innovation or flexibility, this case presents the interconnected whole of Kerala's Covid-19 innovations and flexibility. With a strong inbuilt social fabric, experienced leadership that withered Nipah-virus outbreak, and robust public health system at its advantage, Kerala's Covid-19 recovery strategy involves a flexible system of intertwined social, policing, communication, and technological innovations.

Theoretically, this research contributes an empirical study on a successful innovation system for pandemic management within the Flexible Systems Management literature (e.g. Sushil 1997, 2001). Methodologically, it provides an improved approach employing systems thinking and storytelling for analysing successful innovation systems with flexibility, thereby extending the literature stream linking flexible systems management and systems 
thinking (e.g. Elias 2019). To a practising manager in pandemic management, it offers a method for analysing successful innovations holistically. While acknowledging the limitations of robust theoretical links, this case attempts to develop a new stream of innovation systems in the Flexible Systems Management literature by highlighting the role of stakeholder or actor networks (Rowley 1999) connected to triple/quadruple or quintuple-helix innovation system models (Carayannis et al. 2017).

This study is limited to the first half of 2020 when Kerala recovered successfully from the Covid-19 pandemic. But Kerala's Covid-19 story does not end here. After hitting 5 days of zero new cases in May 2020, Kerala's Covid-19 cases have increased exponentially during the second half of 2020, when Keralites returned home from other states and countries. This new and difficult phase forces Kerala to develop new recovery strategies, based on a different set of innovations and flexible systems. The emerging stakeholder networks to combat these new challenges present two opportunities. First, it presents the scope to develop this case further by analysing the underlying structure behind an exponential increase in Covid-19 cases. Second, it allows further theoretical developments by strengthening the links of this study with the innovation systems literature. Finally, this case may encourage further empirical research, not just on Covid-19, but on other pandemics as well, using a systems thinking approach.

\section{References}

Ackoff, R. L. (1981). Creating the corporate future. . Wiley.

Athira, M., (2020). How Kerala Police is making waves in social media. The Hindu. https://www.thehindu.com/life-and-style/ how-kerala-police-is-creating-waves-on-social-media/article311 41457.ece

Babu, R., (2020). Covid-19: In Kerala, rivals CPI(M) and RSS run community kitchens in concert. Hindustan Times. https://www. hindustantimes.com/india-news/coronavirus-pandemic-bringssworn-enemies-together-in-north-kerala/story-8ZgsN36D1wplP 65KZosGEK.html

Baveja, A., Kapoor, A., \& Melamed, B. (2020). Stopping Covid-19: A pandemic-management service value chain approach. Annals of Operations Research, 289, 173-184.

Bergek, A., Jacobsson, S., Carlsson, B., Lindmark, S., \& Rickne, A. (2008). Analyzing the functional dynamics of technological innovation systems: A scheme of analysis. Research Policy, 37(3), 407-429.

Bishwas, S. K. (2015). Achieving organization vitality through innovation and flexibility: An empirical study. Global Journal of Flexible Systems Management, 16(2), 145-156.

Biswas, S., (2020). Coronavirus: How India's Kerala state 'flattened the curve. BBC News. https://www.bbc.com/news/world-asiaindia-52283748

Brocklesby, J., \& Cummings, S. (1995). Combining hard, soft, and critical methodologies in systems research: The cultural constraints. Systems Research, 12(3), 239-245.
Carayannis, E. G., Grigoroudis, E., Campbell, D. F., Meissner, D., \& Stamati, D. (2018). The ecosystem as helix: An exploratory theory-building study of regional co-opetitive entrepreneurial ecosystems as Quadruple/Quintuple Helix Innovation Models. $R \& D$ Management, 48(1), 148-162.

Carlsson, B., Jacobsson, S., Holmén, M., \& Rickne, A. (2002). Innovation systems: Analytical and methodological issues. Research Policy, 31(2), 233-245.

Checkland, P. (1985). From optimizing to learning: A development of systems thinking for the 1990s. Journal of the Operational Research Society, 36(9), 757-767.

Chowdhury, R., \& Jangle, N. (2018). Critical systems thinking towards enhancing community engagement in micro-insurance. Global Journal of Flexible Systems Management, 19(3), 209-224.

Coyle, G. (1996). System dynamics modelling: A practical approach. . Chapman and Hall.

Dass, V., (2020). The Kerala way: Use of geofencing, drones, telemed app to tackle Covid-19. Express Computer. https://www. expresscomputer.in/indiaincfightscovid19/the-kerala-way-useof-geofencing-drones-telemedicine-app-to-tackle-covid-19/ $52853 /$

Davies, J., Mabin, V. J., \& Balderstone, S. J. (2005). The theory of constraints: A methodology apart?-a comparison with selected OR/MS methodologies. Omega, 33(6), 506-524.

Eidelwein, F., Piran, F. A. S., Lacerda, D. P., Dresch, A., \& Rodrigues, L. H. (2018). Exploratory analysis of modularization strategy based on the theory of constraints thinking process. Global Journal of Flexible Systems Management, 19(2), 111-122.

Elias, A.A., (2008). Group model building: energy efficiency in New Zealand's residential sector. In: Proceedings of the 6th Annual Australian and New Zealand Academy of Management Operations Management Symposium, Gold Coast, 9-10 June. https:// scholar.google.com/scholar?cluster=16935275780737348762 \&hl=en\&oi=scholarr

Elias, A. A. (2017). Systems thinking and modelling for stakeholder management. IIM Kozhikode Society and Management Review, 6(2), 123-131.

Elias, A. A. (2019). Strategy development through stakeholder involvement: A New Zealand study. Global Journal of Flexible Systems Management, 20(4), 313-322.

Elias, A. A., \& Davis, D. (2018). Analysing public sector continuous improvement: A systems approach. International Journal of Public Sector Management, 31(1), 2-13.

Elias, A. A., Cavana, R. Y., \& Jackson, L. S. (2001). Stakeholder analysis to enrich the systems thinking and modelling methodology. In: Proceedings of the 19th International Conference of the Systems Dynamics Society, Atlanta, 23-27 July, 52-70. https://proceedings.systemdynamics.org/2001/papers/Elias_1. pdf

Elias, A., \& Zwikael, O., (2007). Stakeholder Participation in Project Management: A New Zealand Study. In: Proceedings of the 5th Annual Australian and New Zealand Academy of Management Operations Management Symposium, Melbourne, 7-8 June, 1-12. https://scholar.google.co.nz/scholar?hl=en\&as_sdt= $0,5 \&$ cluster $=12715129058540373181$

Faleiro, S., (2020). What the world can learn from Kerala about how to fight covid-19. https://www.technologyreview.com/2020/04/ 13/999313/kerala-fight-covid-19-india-coronavirus/

Galanakis, K. (2006). Innovation process. Make sense using systems thinking. Technovation, 26(11), 1222-1232.

George, G., Lakhani, K. R., \& Puranam, P. (2020). What has changed? The impact of Covid pandemic on the technology and innovation management research agenda. Journal of Management Studies, 57(8), 1754-1758. 
GoK Dashboard. (2020). Kerala: Covid-19 Battle. https://dashboard. kerala.gov.in/

Gorod, A., Gandhi, S. J., Sauser, B., \& Boardman, J. (2008). Flexibility of system of systems. Global Journal of Flexible Systems Management, 9(4), 21-31.

Haleem, A., Kumar, S., \& Luthra, S. (2018). Flexible system approach for understanding requisites of product innovation management. Global Journal of Flexible Systems Management, 19(1), 19-37.

Höglund, L., \& Linton, G. (2018). Smart specialization in regional innovation systems: A quadruple helix perspective. $R \& D$ Management, 48(1), 60-72.

Jovel, J., \& Jain, R. (2009). Impact of identified causal factors to "system of systems" integration complexity from a defense industry perspective. Global Journal of Flexible Systems Management, 10(4), 45-54.

Kerala State Planning Board. (2019). Economic Review 2019. http:// spb.kerala.gov.in/images/pdf/whats_new/ER_2019_Vol1_E.pdf

Lee, S. M., \& Trimi, S. (2020). Convergence innovation in the digital age and in the COVID-19 pandemic crisis. Journal of Business Research, 123, 14-22.

Maani, K. E., \& Cavana, R. Y. (2007). Systems thinking, system dynamics: Managing change and complexity. . Pearson Education.

Malaviya, P., \& Wadhwa, S. (2005). Innovation management in organizational context: An empirical study. Global Journal of Flexible Systems Management, 6(2), 1-14.

Malayala Manorama. (2020). Migrant labourers hit the streets in Kerala's Paippad defying lockdown. Malayala Manorama. https://english. manoramaonline.com/news/kerala/2020/03/29/kerala-migrantlabourers-protest-defying-lockdown-paippad.html

Manoj, P. K. (2016). Foreign remittances of the non-resident Keralites: A study of its impacts on Kerala based private banks. International Journal of Trade and Global Business Perspectives, 5(1), 170-178.

Mathrubhumi. (2020). Courier service to deliver medicines to NRKs; Antibody tests among essential service workers. https://english. mathrubhumi.com/news/kerala/courier-service-to-deliver-medi cines-to-nrks-antibody-tests-among-essential-service-workers-1. 4711330

Nelson, R. R., \& Green, K. (1996). National innovation systems: A comparative analysis. $R \& D$ Management, 26(2), 191-191.

Nossiter, T. J. (1982). Communism in Kerala: A study in political adaptation. . University of California Press.

Paul, S. K., \& Chowdhury, P. (2020). Strategies for managing the impacts of disruptions during COVID-19: An example of toilet paper. Global Journal of Flexible Systems Management, 21(3), 283-293.

Polas, M. R. H., \& Raju, V. (2021). Technology and entrepreneurial marketing decisions during COVID-19. Global Journal of Flexible Systems Management. https://doi.org/10.1007/s40171021-00262-0.

Prakash, B. A. (2020). What Kerala paid for being India's model Covid state. https://timesofindia.indiatimes.com/india/what-ker ala-paid-for-being-indias-model-covid-state/articleshow/ $75178569 . \mathrm{cms}$

Press Trust of India. (2020). Coronavirus: Community kitchens dish out 2.8 lakh food packets a day in Kerala. https://yourstory.com/ 2020/04/coronavirus-community-kitchen-kerela-food-packets

Raval, A. (2020). How states have partnered with startups to fight COVID-19. Express Computer. https://www.expresscomputer. in/indiaincfightscovid19/how-states-have-partnered-with-start ups-to-fight-covid-19/54737/

Richmond, B. (1994). System dynamics/systems thinking: Let's just get on with it. System Dynamics Review, 10(2-3), 135-157.

Rowley, T. J. (1997). Moving beyond dyadic ties: A network theory of stakeholder influences. Academy of Management Review, 22(4), 887-910.
Sarkar, S. (2021). Breaking the chain: Governmental frugal innovation in Kerala to combat the COVID-19 pandemic. Government Information Quarterly, 38(1), 101549.

Sterman, J. D. (2000). Business dynamics: Systems thinking and modeling for a complex world. Irwin McGraw-Hill.

Sushil. (1997). Flexible systems management: An evolving paradigm. Systems Research and Behavioral Science, 14(4), 259-275.

Sushil. (2001). SAP-LAP Models. Global Journal of Flexible Systems Management, 2(2), 55-61.

Sushil. (2017). Flexible systems management as an iterative process. Global Journal of Flexible Systems Management, 8, 87-88.

The Hindu. (2020). Community kitchens supplying 2.8 lakh food packets daily. https://www.thehindu.com/news/cities/Kochi/ more-food-to-be-prepared-at-community-kitchens/article313107 76.ece

The New Indian Express. (2020). Coronavirus: Kerala CM Pinarayi Vijayan, Opposition leader urge local bodies to work proactively. https://www.newindianexpress.com/states/kerala/2020/ mar/20/coronavirus-kerala-cm-pinarayi-vijayan-opposition-lea der-urge-local-bodies-to-work-proactively-2119153.html

Ulrich, W. (1983). Critical heuristics of social planning: A new approach to practical philosophy. . Wiley.

Von Krogh, G., Kucukkeles, B., \& Ben-Menahem, S. M. (2020). Lessons in rapid innovation from the COVID-19 pandemic. MIT Sloan Management Review, 61(4), 8-10.

Wadhwa, S., Madaan, J., \& Saxena, A. (2007). Need for flexibility and innovation in healthcare management systems. Global Journal of Flexible Systems Management, 8(1-2), 45-54.

WHO. (2018). Nipah virus- India. https://www.who.int/csr/don/07august-2018-nipah-virus-india/en/

Zwikael, O., Elias, A. A., \& Ahn, M. (2012). Stakeholder collaboration and engagement in virtual projects. International Journal of Networking and Virtual Organisations, 10(2), 117-136.

Publisher's Note Springer Nature remains neutral with regard to jurisdictional claims in published maps and institutional affiliations.

\section{Key Questions Reflecting Applicability in Real Life}

1. How can innovative approaches coupled with flexible systems help in managing the current and post Covid-19 world?

2. What can the South Indian state of Kerala teach the world about Covid-19 recovery strategies?

3. Methodologically, how can storytelling approaches enrich systems thinking?

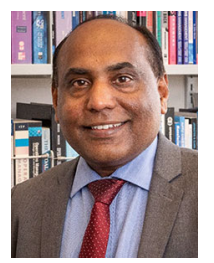

Arun A. Elias is the Associate Dean (International and Accreditation) at the Victoria Business School, Victoria University of Wellington, New Zealand. His main research interests are in the areas of stakeholder management, systems thinking and operations management. He holds a $\mathrm{PhD}$ in Management from Victoria University of Wellington, a Master of Industrial Engineering and Management from IIT Kharagpur and another Master of Agricultural Engineering from Allahabad University. He has published in journals like Energy Policy, R\&D Management and International Journal of Logistics Management. He currently serves as the Regional Editor, Asia Pacific Region for the Global Journal of Flexible Systems Management and is a guest editor for this special issue. 